\title{
PERSEPSI MAHASISWA TENTANG KOMPETENSI KEPRIBADIAN DOSEN PROGRAM STUDI PENDIDIKAN BIOLOGI FKIP-UIR PEKANBARU
}

\author{
(Students' Perception on Lecturer's Personality Competency for Biology Education Program of \\ FKIP-UIR Pekanbaru) \\ Oleh: Suryanti, Sudarmi, dan Afnila Fitradini Har*) \\ E-mail : suryanti@gmail.com
}

*) Program Studi Pendidikan Biologi, Universitas Islam Riau

\begin{abstract}
This study purposed to determine students' perception regarding the lecturer personality competencies. The method of study was survey. Research instrument was using questionnaires, observation, interviews, and documentation. The population in this study was in third year, semester VI students (class A, B, C). The number of population was 106 students with high, medium, and low academic abilities in their third year semester VI. Sampling method was using saturated samples. Data analysis used descriptive method. The result of personality competency research, with 5 indicators of high, medium and low academic abilities, for $1^{\text {st }}$ indicator, which stated as act in accordance with the Norms of Religion, Law, Social and Culture of the Indonesian Nation, an average of 98.10 categories as very good, for indicator 2 stated as self portray as a person who was honest, noble, and exemplary for students and the community an average of 85.97 categories as very good. Indicator 3, which was showing yourself as a person who was steady, stable, mature, wise, and authoritative, on average 84.40 categories as very good. Indicator 4, demonstrated work ethic, high responsibility, pride in being a teacher, and self-confidence, on average 83.40 categories as very good. Indicator 5, mention as upholding the ethics code of the teaching profession, averaging in 78.75 as good categories.
\end{abstract}

Key Word; Students' Perception, Lecturer Personality Competencies, High, Medium and Low Academic Student Ability

\section{PENDAHULUAN}

Pendidikan dapat mencerdaskan kehidupan bangsa, untuk mencapai atau merealisasikan tujuan itu, pemerintah membuat strategis pencapaiannya melalui sistem pendidikan nasional. Perubahan dari system ini dalam penyelenggaraan pendidikan dilakukan secara berjenjang mulai dari tingkat dasar sampai perguruan tinggi sebagai jalur mencerdaskan sumberdaya manusia yang harapkan sebagai penerus sumber daya manusia. Berbagai regulasi telah dibuat oleh pemerintah sebagai landasan yuridis dalam operasionalisasi pendidikan nasional secara bertahap dan berkelanjutan terus dikembangkan, peraturan-peraturan yang mendasari pelaksanaan pendidikan terus ditelorkan dari waktu ke waktu. Undang-undang No.20 tahun 2003 tentang Sistem Pendidikan Nasional. Guru (dosen) adalah secara umum pendidikan, sebagai faktor utama dalam menentukan mutu 
proses belajar mengajar. merekalah berinteraksi atau berhubungan langsung dengan siswa (mahasiswa) di dalam kelas, indikator ilmu pengetahuan dan teknologi, sekaligus menanamkan nilainilai karakter yang positif melalui bimbingan dan uswatun hasanah. Dipundaknya juga akan lahir peserta didik (mahasiswa) yang bermutu tinggi baik secara kognitif, psikomotor, afektif serta spiritual.

Diperlukan sosok guru (dosen) tidak hanya memiliki kualifikasi, kompetensi dan dedikasi, tetapi juga memiliki pribadi yang menginspirasi peserta didik, bahwa Anak-anak akan merasa senang jika diperlakukan dengan baik dan hangat penuh rasa saling menghargai satu dengan yang lainnya, sumber utama kebahagiaan mereka diperlakukan seperti itu, maka mereka akan senang memperlakukan orang lain, hewan bahkan benda mati dengan baik dan hangat (Lickona, 2012).

Persepsi merupakan suatu proses yang didahului oleh penginderaan, yaitu merupakan suatu proses penerimaan, penilaian, pengorganisasian dan penginterprestasian seseorang atau sekelompok orang terhadap suatu objek, yang kemudian dilanjutkan dengan proses psikologi di dalam otak, sehingga individu dapat menyadari dan memberikan makna terhadap objek yang telah diinderakannya, melalui persepsi manusia terus menerus mengadakan hubungan dengan lingkungannya. Hubungan ini dilakukan lewat inderanya, yaitu indera penglihatan, pendengaran, perasa dan pencium dan melalui persepsi mahasiswa memberikan pandangan (Slameto, 2013).

Kompetensi guru (dosen) merupakan kemampuan seorang dalam melaksanakan kewajiban-kewajiban secara bertanggung jawab dan layak. Kompetensi yang dimilki akan menunjukkan kualitas dalam menagajar. Kompetensi tersebut akan terwujud dalam penguasaan pengetahuan dan profesional dalam menjalankan fungsinya. Artinya bukan saja harus pintar, tetapi juga harus pandai mentransfer ilmunya kepada peserta didik (Fathurrahman, Pupuh, dan Sutikno, 2009). Kompetensi yang dimaksud meliputi kompetensi pedagogik, kompetensi kepribadian, kompetensi sosial, dan kompetensi profesional. Keempat kompetensi yang dalam penerapannya saling mempengaruhi dan tidak bisa lepas antara satu dengan yang lain. Selain itu, kompetensi juga harus mempunyai kualifikasi akademik yang dibuktikan dengan sertifikat keahlian yang diperoleh melalui sertifikasi sebagai bentuk penguasaan kompetensi (Kunandar, 2014).

Kompetensi kepribadian mewajibkan dimiliki oleh setiap guru (dosen), kemampuan personal yang mencerminkan kepribadian yang mantab dan stabil, arif dan bijaksana, berwibawa, dewasa, berakhlak mulia, dan menjadi teladan bagi peserta didik (mahasiswa). Kemampuan yang terpancar lewat perilaku dan tindakan sehari-hari serta memberikan gambaran tentang diri sendiri atau profesi yang diperankan. Dalam hal ini harus memiliki kepribadian yang mantap sehingga mampu mengendalikan proses perkuliahan sesuai dengan kebutuhan dan kondisi $\mathrm{p}$ serta menjadi sumber inspirasi. Guru (dosen) adalah salah satu komponen manusiawi dalam proses belajar mengajar, yang ikut berperan dalam usaha pembentukan sumber daya manusia yang potensial dibidang pembangunan, juga merupakan salah satu unsur dibidang kependidikan 
harus berperan secara aktif dan menempatkan kedudukannya sebagai tenaga profesional, sesuai tuntutan masyarakat yang semakin berkembang dan bersifat dianamis (Sardiman, 2012).

Kemampuan dalam pelaksaan pembelajaran ada 4 tahapan seperti yang diungkapkan di atas, telah dilakukan penelitian tentang Kemampuan Pedagogik di Program Studi Biologi Fakultas Keguruan dan Ilmu pendidikan Universitas Islam Riau, penelitian ini melanjutkan pada kompetensi kedua yaitu kemampuan kepribadian. Harapan peneliti mendapatkan gambaran secara utuh dan bijak tentang kemampuan mengajar para dosen yang ada di Program Studi BiologiBiologi

Hasil wawancara dan observasi tentang kepribadian diperoleh informasi sebagaimana kondisi yang terjadi di lapangan: (1) secara sopan santun semua dosen sudah baik (2) mencerminkan kepribadian yang mantap dan stabil secara mayoritas tapi masih ada beberapa yang belum dan ini sifatnya situasional (3) secara umum mencerminkan keraifan secara pribadi walaupun belum maksimal (4) untuk kebijaksaan dalam hal menilai proses dan hasil mayoritas sudah bagus (5) secara keseluruhan memiliki wibawa yang baik tapi masih ada yang tidak memiliki wibawa dalam proses pembelajaran (6) mayoritas cukup dewasa dalam menyikapi mahasiswa, berahlak mulia dan sopan berpakaian dan mampu menjadi teladan yang baik.

Alasan melakukan penelitian ini karena ada 4 kompetensi dosen, untuk kompetensi yang 1 ( Kompetensi Pedagogik) telah dilakukan penelitian di Program Studi Biologi FKIP UIR, untuk selanjutnya yang akan diteliti tentang Kompetensi 2 (kemampuan kepribadian), karena sangat menentukan interaksi antara mahasiswa dan dosen, jika kondisi di atas tidak berjalan sebagaimana mestinya bagaimana kita bisa menghasil lulusan yang dapat berkompetesi di luar sana. Disini dosen dijadikan model untuk ditiru terutama dalam proses pengajaran karena hal ini juga dapat dapat mempengaruhi mahasiswa secara pribadi untuk tertarik atau tidak terhadap materi yang disajikan pada perkuliahan. Dapat digunakan sebagai gambaran mahasiswa nanti pada waktu menjadi tenaga pengajar, jika dalam pelaksanaannya tidak memiliki pribadi yang baik. Akan berakibat kedalam banyak hal seperti nilai, semangat dan lain-lain.

Diperkuat oleh hasil penelitian (Darojah \& Hadijah, 2016) Analisis Pengaruh Kompetensi Kepribadian Guru Dengan Motivasi Belajar Sebagai Variabel Intervening Terhadap Prestasi Belajar Siswa Kelas X Administrasi. Hasil penelitian menunjukkan bahwa kompetensi kepribadian guru berpengaruh positif dan signifikan terhadap motivasi belajar siswa, sehingga dapat disimpulkan bahwa semakin tinggi kompetensi kepribadian guru maka semakin tinggi pula motivasi belajar siswa. Motivasi belajar siswa berpengaruh positif terhadap prestasi belajar siswa, sehingga dapat disimpulkan semakin tinggi motivasi belajar siswa maka semakin tinggi pula prestasi belajar siswa. Kompetensi kepribadian guru berpengaruh positif dan signifikan secara langsung maupun tidak langsung terhadap prestasi belajar siswa melalui motivasi belajar siswa. Maka penelitian ini bertujuan untuk mengetahui Persepsi Mahasiswa Akademik Tinggi, sedang dan rendah Tentang Kompetensi Kepribadian Dosen Program Studi Pendidikan Biologi FKIP-UIR Pekanbaru. 


\section{METODE PENELITIAN}

Penelitian ini telah dilaksanakan pada Program Studi pendidikan Biologi FKIPUIR Pekanbaru. Pada bulan Mei November Tahun 2019. Jenis penelitian ini adalah Survei. Populasi dalam penelitian ini mahasiswa tingkat III semester VI (A.B.C) berjumlah 106 orang. Pengambilan sampel menggunakan sampel jenuh. Dimana semua populasi diambil sebagai sampel (Sugiyono,2014) dengan Kemampuan mahasiswa Akademik Tinggi, Sedang dan Rendah. Instrument penelitian menggunakan angket dengan lima indikator, berisi 41 item pertanyaan, observasi, wawancara, dokumentasi. Dari indikator untuk mengetahui setiap jawaban pertanyaan maka digunakan skala Likert. Skala dalam penelitian menggunakan lima katagori yaitu sangat sering, sering cukup sering, kadang- kadang dan tidak pernah. Pengisian angket ini dengan memberi tanda checklist $(\sqrt{ })$ pada jawaban yang sesuai menurut responden. Untuk validitas konten dan isi dilakukan oleh teman sejawat Tengku Idris S.Pd.M.Pd. Tehnik analisis data digunakan peneliti adalah analisis deskriptif.

HASIL DAN PEMBAHASAN

Rata-Rata Per Indikator Kompetensi Kepribadian untuk Kemampuan Akademik Tinggi, Sedang dan Rendah

Data yang didapat dalam penelitian ini tentang Persepsi Mahasiswa Tentang Kompetensi Kepribadian Dosen Program Studi Pendidikan Biologi, RataRata dari lima Indikator untuk Kemampuan Mahasiswa Akademik Tinggi, Sedang dan Rendah untuk lebih jelas dapat dilihat pada gambar 1 di bawah ini;

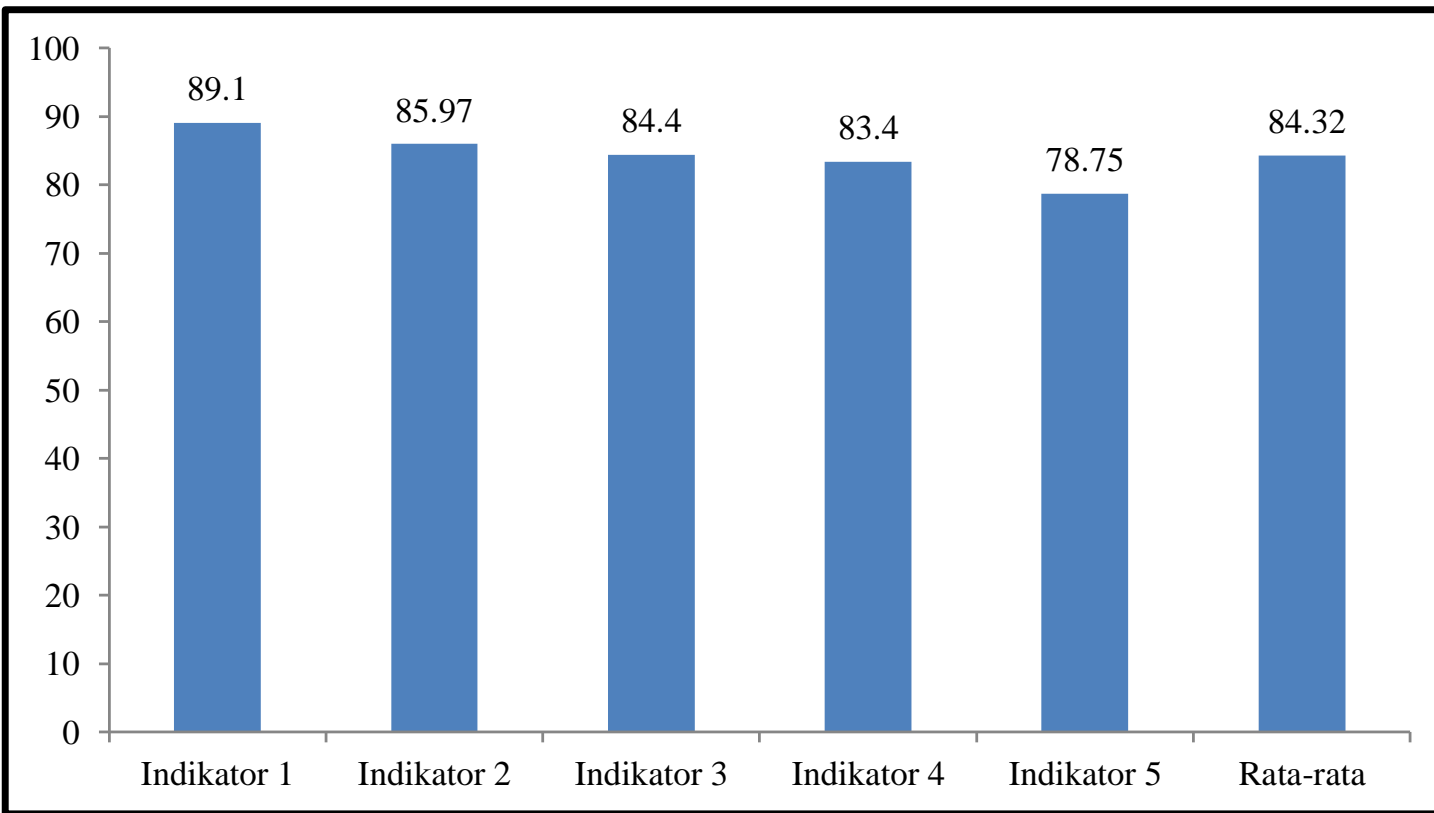

Gambar 1. Grafik Rata-Rata Secara Keseluruhan Kompetensi Kepribadian Berdasarkan Kemampuan Akademik Tinggi,Sedang dan Rendah 
Data garfik di atas didapat penjelasan mengenai Persepsi Mahasiswa tentang Kompetensi Kepribadian dengan Kemampuan Akademik Tinggi, Sedang dan Rendah , dari lima indikator maka indikator 1 yaitu Bertindak sesuai dengan Norma Agama, Hukum, Sosial dan Kebudayaan Nasional Indonesia, rata-rata 89.1 dengan katagori sangat baik. Didalam proses belajar mengajar dosen harus mempunyai peranan ganda sebagai sutradara sekaligus aktor, artinya keberhasilan mereka terletak bagaimana memerankan proses, karena dosen merupakan faktor yang sangat dominan disamping faktor-faktor lainnya. Untuk mencapai hal itu dosen harus mempunyai kemampuan dasar untuk melaksanakan tugasnya, diantaranya kemampuan pribadi sendiri. Untuk itu ada beberapa hal yang perlu diperhatikan bila berperan sebagai dosen diantaranya; memahami tatanan norma-norma karena merupakan aturan, standar, ukuran, batasan-batasan perilaku yang manusiawi, serta panduan hidup yang mengatur hubungan antara manusia dengan manusia sekaligus antara manusia dengan Tuhannya, serta pengaturan tata perilaku yang bersifat wajib untuk dipatuhi oleh setiap masyarakat yang ada didalamnya, bersifat heteronom (norma hukum itu datang dari luar diri seseorang) dan norma lain bersifat otonom (norma itu berasal dari diri seseorang), dan perilaku sosial dalam bermasyarakat dan tindakan sosial yang sifatnya preventif. Secara internal manusia dan masyarakat memiliki intuisi dan aspirasi untuk mencapai kemajuan. Karena pengaruh dari luar selalu mendorong masyarakat, yang dinilai statis sekali pun, untuk bereaksi terhadap rangsangan dari lingkungannya. Saat ini bisa berasal dari media masa, melalui pemberitaan maupun pembentukan opini.
Pengaruh internal dan khususnya eksternal ini merupakan faktor strategis bagi terbentuknya suatu kebudayaan nasional. Sistem dan media komunikasi menjadi sarana strategis yang dapat diberi peran strategis pula untuk memupuk identitas nasional dan kesadaran nasional. Menurut penelitian (Abdullah. Getteng \& Nuryamin., 2018), Mendidik Mahasiswa bukanlah suatu pekerjaan yang mudah apalagi dilakukan secara serampangan akan tetapi merupakan pekerjaan yang membutuhkan pengetahuan tentang ilmu pendidikan, mencintai anak didik, senantiasa intens dalam hal mendidik sesuai dengan norma-norma yang berlaku, ikhlas dalam beramal, serta mempelajari kebiasaan dan watak anak didiknya. Dari hal diatas maka sebaiknya seorang dosen faham betul tentang norma yang mengatur kehidupan ini, agar proses belajar mengajar yang dilakukan dapat berjalan dengan lancer dan baik sesuai dengan ketentuan yang berlaku. Diperkuat penelitian oleh (Andina, 2018) Pelaksanaan tugas sebagai guru harus didukung oleh suatu perasaan bangga akan tugas yang dipercayakan kepadanya untuk mempersiapkan generasi kualitas masa depan bangsa. Dengan kata lain seorang guru harus memiliki passion yang tercermin dalam tata nilai norma, moral, estetika, dan ilmu pengetahuan yang nantinya memengaruhi perilaku etik siswa sebagai pribadi dan anggota masyarakat.

Untuk Indikator 2 yaitu menampilkan diri sebagai pribadi yang jujur, berahlak mulia, dan teladan bagi peserta didik dan masyarakat dengan rata-rata 85.97 dengan katagori Sangat baik. Hal ini perlu ada penekanan bagi seorang dosen untuk memiliki karakter yang kuat dari semua karakter yang ada, 
agar dapat menampilkan diri secara pribadi terutama dalam hal jujur, sebab sifat jujur tidak semua orang mampu menerapkaanya terutama yang sudah terlatih sejak kecil untuk menegakkan sifat jujur. Tampa kebiasaan hal ini sulit dilakukan oleh pribadi, karena jujur mencerminkan dosen memiliki budi mulia atau berahlak mulia serta dapat memberikan teladan kepada mahasiswa dalam berbicara, berpakaian, menciptakan prakarsa dan ide, tindakan yang baik di tengah atau di antara mahasiswa, dosen selama proses pembelajaran sehingga secara otomatis dosen itu juga beriman. Hasil penelitian (Rochmawati, 2018) penanaman semua karakter pada setiap individu sangat penting agar sumber daya manusia ke depan dapat diandalkan dengan baik, dalam kehidupan secara pribadi maupun dalam kehidupan berbangsa. Untuk itu peran dosen dan lingkungan penting dalam menanamkan karakter jujur. Pentingnya dosen memiliki kompetensi kepribadian agar efektif dan efisien agar bisa memberi keteladanan yang baik terhadap anak didiknya. Disamping itu kejujuran sebuah yang penting bagi kehidupan. Sehingga setiap individu memiliki pemahaman akan perbedaan karakter baik dan buruk serta apa konsekwensinya. Salah satu upaya yang dilakukan adalah dengan menerapkan konsep pendidikan di kampus yang membebaskan mahasiswa artinya pendidikan tidak berbicara tentang akademik semata melainkan harus dapat membentuk karakter dan lainnya.

Hal ini sangat penting diterapkan kepada mahasiwa terutama melatih kejujuran dan nilai lainnya. Maka Kejujuran, berahlak mulia dan keteladanan sebagai suatu nilai, seharusnya tidak lagi dipandang sebagai harga material, yang hanya sebatas kebutuhan hidup saja, tetapi menjadi harga yang inmaterial, sehingga telah menjadi esensi hidup yang akan melekat pada diri, yang tidak lekang oleh kondisi dan waktu. Menurut (Jamil, 2012) Kepribadian yang berahlak mulia dapat dilihat dari kereligiusitasannya sesuai dengan agama yang dianut, kejujuran dalam perkataan dan perbuatan, dan tindakan-tindakan yang sesuai dengan norma agama. Dipekuat oleh (Ave dalam Dost \& Hafshejani, 2017) Guru memiliki pengaruh penting terhadap prestasi akademik siswa dan juga memainkan peran penting dalam pencapaian pendidikan karena guru bertanggung jawab untuk melakukan kebijakan pendidikan dan kualitas pendidikan. Maka kepribadian dan perilaku guru sangat penting untuk diperhatikan, karena banyak guru telah meremehkan dampaknya perilaku dan kepribadian terhadap karakter siswa.

Indikator 3 yaitu menampilkan diri sebagai pribadi yang mantap dan stabil, dewasa, arif,dan berwibawa, ratarata 84,40 dengan katagori sangat baik. Karena dengan kepribadian yang mantap berarti sorang dosen harus bersifat tetap hati, kukuh, kuat, tidak berubah dalam bersikap sebagai seorang pengajar terutama di perguruan tinggi karena levelnya sudah berbeda jika kita tidak sesuai bersikap maka akan dinalai tidak baik oleh mahasiswa, kemudian harus stabil, tidak mudah dipengaruhi yakin apa yang ia putuskan adalah yang terbaik dan tidak ada istilah pilih kasih, sehingga sulit melaksanakan tugasnya dengan baik, untuk itu perlu sikap stabil, merupakan sikap seorang dosen yang sangat perlu dan dibutuhkan dalam menjalankan profesinya. orang-orang yang memiliki pendirian yang kuat dan komitmen yang 
tinggi serta sikap yang mantap dan stabil. Kemudian sikap kedewasaan juga dibutuhkan, karena umur seseorang tidak bisa jadi jaminan seseorang menjadi dewasa, bila dianggap dewasa seorang dosen harus mempunyai kematangan berpikir atau pandangan yang luas, demikian pula sikap arif serta bijaksana merupakan kepribadian yang harus ada disetiap dosen terutama dalam mendidik mahasiswanya. Jika ia arif otomatis ia juga bijaksana, dan memunculkan wibawa seorang guru dapat tercermin dalam menghadapi proses pada kegiatan pembelajaran yang memahami dengan baik ilmu yang dipelajari dan miliki untuk dapat diterapkan. Menurut pendapat (Eprijum dan Ginanto, 2010) menegaskan bahwa dosen / guru adalah sosok pahlawan yang jasanya tiada tara. Mereka adalah pejuang dengan bersenjatakan pena, yang mampu mengubah batu menjadi batu mulia. Perjuangan mereka tulus, bagai sinar mentari yang menyinari bumi. Perilakunya dapat ditiru dan perkataannya selalu digugu, serta dia mempunyai wibawa dan kharisma luar biasa. Wibawanya ditentukan oleh sikap santunya. Jika sikap santun guru merosot maka wibawanyapun merosot, dan jika sikap santunya baik, wibawanya juga menjadi baik. Oleh karena itu setiap guru diharapkan memiliki sikap santun dalam menghadapi setiap peserta didiknya. Penelitian oleh (Nahampun, 2017), memiliki kompetensi kepribadian yang mantap dan stabil dengan bertindak sesuai dengan norma, dan memiliki kebanggaan yang dapat dilihat dari kemampuan subjek dalam melaksanakan tugas dan tanggung jawab dengan sepenuh hati, bersikap arif dan bijaksana dalam memberikan pembelajaran yang bermanfaat, persiapan pembelajaran tidak hanya sebatas penyusunan RPP tetapi lebih pada persiapan mental, berpenampilan dan berperilaku yang penuh kewibawaan sehingga anak-anak memiliki rasa hormat, segan. Memiliki kepribadian dewasa tampak dari kemampuan dalam mengendalikan emosi, menerima anak apa adanya, memperlakukan anak dengan penuh kasih sayang, dan menerima kritikan dan saran sebagai sarana untuk evaluasi diri dan memperluas wawasan.

Mencerminkan kepribadian yang sesuai dengan undang-undang tentang guru dan dosen. Dapat dilihat dalam Undang-undang nomor 14 tahun 2005 tentang guru dan dosen dan (Suprihatiningrum, 2014), dikemukakan bahwa; seorang guu atau dosen dikatakan memiliki kompetensi kepribadian yang baik apabila memenuhi 6 aspek yakni memiliki kepribadian yang mantap dan stabil, arif dan bijaksana, berwibawa, dewasa, berahlak mulia, dan mampu menjadi teladan bagi peserta didik. Aspek-aspek tersebut tercermin lewat sikap, tindakan, dan perkataan dosen dan guru. Diperkuat (Dost \& Hafshejani, 2017) hubungan antara kepribadian guru dan efektifitas pengajaran, akan membantu mengidentifikasi dalam memilih metode pengajaran terbaikyang sesuai dengan kepribadian agar proses pengajaran menjadi efektif.

Indikator 4 yaitu Menunjukkan etos kerja, bertanggung jawab yang tinggi, rasa bangga menjadi guru, dan rasa percaya diri, rata-rata 83,40 dengan katagori baik. Disini dituntut bagi seorang dosen memiliki etos kerja, secara pribadi akan memiliki tanggung jawab yang besar dalam proses mendidik dan mengajar kepada mahasiswa, karena dapat menghargai pekerjaan sebagai 
bagian dari hidupnya untuk meningkatkan kehidupannya. Sebab, tanpa ini semua, hasil kerja yang diharapkan sulit dicapai. Secara pribadi seorang dosen harus punya rasa tanggung jawab moral yang tinggi menyangkut; harus bersikap suka dan rajin bekerja keras dengan penuh energi, efektif, tepat waktu, efisien, suka bekerja sama, jujur dan loyal diikuti dengan prestasi tinggi, tidak saja pada waktu mengajar tapi juga bertaggung jawab mengembangkan dalam bidang pendidikan. Rasa bangga menjadi dosen, sebagai standar normal yang dirasakan, karena memiliki potensi (kemampuan) yang terdapat di dalam jiwa manusia, untuk menunjukkan rasa senang, lega, puas muncul dalam hati seseorang sebagai suatu reaksi atas keberhasilan setelah ia melakukan sesuatu perbuatan. Seorang dosen harus memiliki rasa percaya diri, karena dapat menyakinkan pada diri sendiri dalam melakukan tugas dan memilih pendekatan yang efektif, juga kepercayaan akan kemampuan menghadapi lingkungan yang semakin menantang serta kepercayaan atas pendapat dan keputusannya dan memiliki sikap posistif terhadap diri sendiri, situasi maupun terhadap lingkungan yang dihadapi. Perlu menciptakan rasa percaya diri tinggi pada mahasiswa, untuk itu kompeten yang kita miliki mampu kita trasnferkan dengan baik. Dari hasil penelitian (Shabir, 2015), Dosen adalah pendidik profesional dengan tugas utama mendidik, mengajar, membimbing, mengarahkan, melatih, menilai, dan mengevaluasi peserta didik. Tugas dan tanggung jawab guru adalah mengajar atau menyampaikan kewajiban kepada peserta didik. Selain itu juga membimbing mereka secara keseluruhan sehingga terbentuk kepribadian muslim yang sesuai. Guru berkewajiban merencanakan pembelajaran secara baik, mengembangkan kualifikasi dan kompetensinya secara berkesinambungan, bertindak objektif, menjunjung tinggi peraturan, memelihara persatuan dan kesatuan bangsa. Maka untuk menjadi sebagai guru yang profesional, ia harus memiliki keahlian khusus yang disebut kompetensi dalam menjalankan tugastugas profesionalnya. Keahlian tersebut meliputi kompetensi pedagogik, kompetensi kepribadian, kompetensi sosial, dan kompetensi profesional. Keempat kompetensi tersebut saling menjalin secara terpadu dalam diri seorang guru. Diperkuat pendapat (Iswidharmanjaya \& Enterprise, 2014) orang yang memiliki etos kerja, bertanggung jawab dan percaya diri lebih mampu dalam menyesuaikan diri dengan lingkungan yang baru, akan lebih mudah berbaur dan beradaptasi, memiliki pegangan kuat, mampu mengembangkan motivasi, ia juga sanggup belajar dan bekerja keras untuk kemajuan, serta penuh keyakinan terhadap peran yang dijalaninya. Menurut (Mart, 2013) Guru yang berkomitmen memiliki kecenderungan untuk melakukan peran secara efektif yang dibutuhkan dalam pekerjaan.

Indikator 5 yaitu Menjunjung tinggi kode etika profesi guru, rata-rata 78.75 dengan katagori baik. Ini menjelaskan bahwa implementasi kode etik guru sangat diperlukan dilakukan dalam melaksanakan tugas dan tanggung jawabnya sebagai seorang pendidik atau dosen karena memberikan pedoman berpikir, bersikap dan berperilaku dalam kegiatan yang dilakukan menuntut tanggung jawab profesi, karena faktor penting berisikan tututan kemampuan dosen dalam proses pembelajaran di 
dalam kelas. Juga dipandang suatu hal yang paling penting dalam memjawab berbagai tantangan dalam dunia pendidikan dewasa ini. Seuai dengan Undang-Undang Republik Indonesia Nomor 1 Tahun 2005 Pasal 42 dan 43 tentang organisasi profesi guru dan dosen salah satunya mempunyai kewenangan menetapkan dan menegakkan kode etik. Serta meningkatkan kehormatan dan martabat guru dan dosen dalam pelaksanaan tugas kepropesionalan organisasi profesi guru dan dosen membentuk kode etik. Kunci keberhasilan dosen dalam meningkatkan pretasi belajar mahasiswa adalah memiliki kode etik yang baik. Adapun tujuan mengimplementasikan kode etik guru dan dosen adalah (1) untuk menjunjung tinggi kode etik guru (2) untuk menjaga dan memelihara kesejahtraan para anggotanya (3) untuk meningkatkan pengabdian anggota profesi (4) untuk meningkatkan mutu profesi (5) untuk meningkatkan mutu organisasi profesi. Diperkuat hasil penelitian Farhan (2018), Pendidik merupakan profesi yang sangat mulia. Keberadaannya menjadi salah satu faktor terpenting dalam sistem pendidikan. Sehingga marwah dan kewibawaan dari profesi ini harus senantiasa dijaga oleh para pendidik. Penjagaan atas kemuliaan tersebut dapat dilakukan dengan melaksanakan kode etik yang menjadi peganggan dalam melaksanakan atifitasnya sebagai pendidik. Dalam era modern, kode etik pendidik telah dirumuskan. Tetapi tampaknya masih belum optimal untuk mampu menjaga marwah pendidik.

Sehingga diperlukan solusi atas problem tersebut, diantaranya dari para pemikir pendidikan dalam lintasan sejarah pendidikan, banyak ditemukan mutiara pemikiran para pemikir pendidikan. Mereka telah memformulasikan dengan baik terkait dengan Kode Etik pendidik. Kode etik pendidik secara garis besar ada tiga hal utama, pertama, terkait dengan keharusan meluruskan niat sebagai pendidik dengan senantiasa meningkatkan kualitas ketakwaan kepada Allah karena mendidik merupakan ibadah. Kedua, harus senantiasa menjaga profesinya dengan memperbaiki kepribadian dengan akhlak yang mulia. Dan ketiga, senantiasa meningkatkan profesionalitasnya sebagai pendidik. Menurut (Abuddin, 2016). Hal itu dapat dipahami dari berbagai problematika yang muncul serta perkembangan zaman yang semakin tidak terbendung. Peran pendidik semakin mengalami perubahan yang signifikan akibat adanya kemajuan dalam berbagai bidang sehingga mengarahkan mereka terjebak pada posisi hedonis, materialis, bahkan pragmatis maka perlu diberlakukan Kode Etik tersebut. Diperkuat pendapat (Foster, 2012) menyatakan bahwa kode etik dapat menjadikan guru sebagai panutan moral dalam kehidupan bermasyarakat.

Kompetensi Kepribadian Dosen Program Studi Pendidikan Biologi dari 5 indikator dengan kemampuan akdemik tinggi, sedang dan rendah maka rata-rata yang di dapat 84.34 dengan katagori sangat baik. Baik yang sudah mengajar lebih dari lima tahun dan yang belum mengajar sampai lima tahuh. Karena merupakan satu kesatuan yang ideal jika seorang dosen memiliki kompetensi secara umum dan secara khusus agar dapat melakukan dan melaksanakan dalam proses belajar mengajar. Diperkuat dari hasil wawancara mahasiswa yang mewakili maka Kompetensi Kepribadian Dosen Program Studi Pendidikan Biologi 
secara umum sudah baik dan harus selalu melakukan evalausi agar sesuai dengan kelima indikator yang digunakan. Sesuai dari hasil penelitian (Garcia, 2011) dan (Ilandou dan Zand, 2011) untuk itu seorang dosen perlu melakukan evaluasi diri mengenai kompetensi kepribadian yang dimiliki. Sehingga ketika merasa dirinya kurang berkompeten dari segi kepribadian, bisa melakukan tindakan yang dapat meningkatkan kompetensinya dengan cara mengikuti pelatihan atau dengan cara berdiskusi dengan sesama guru. Maka sumberdaya didikan kita masih bisa bertahan dengan aturan yang berlaku sampai saat ini atau sebaliknya, sehingga kita mampu menghadapi kerasnya era globalisasi dan milenia saat ini.

\section{KESIMPULAN}

Dari hasil penelitian dapat disimpulkan bahwa Persepsi Mahasiswa Tentang Kompetensi Kepribadia Program Studi Pendidikan Biologi di katagorikan sangat baik.

\section{DAFTAR PUSTAKA}

Abuddin, N., (2016), Inovasi Pendidikan Islam, Jakarta: Salemba Diniyah 2016, Pendidikan dalam Persepektif al-Qur'an, Jakarta:

Andina.,E. (2018). Efektivitas Pengukuran Kompetensi Guru (The Effectiveness of Teacher Competency Measurement). Aspirasi: Jurnal Masalah-Masalah Sosial | Volume 9, No, 2 Desember 2018 ISSN: 2086-6305 (print) ISSN: 2614-5863 (electronic) DOI: https://doi.org/10.22212/aspirasi.v7 i1.1084 link online: http://jurnal.dpr.go.id/index.php/asp irasi/index. di unduh jam 9 malam, tgl 4 september 2019

Abdullah.A., Getteng,R., Nuryamin., (2018). Pengaruh Kompetensi Kepribadian Guru Terhadap Motivasi Belajar Peserta Didik Mtsn 2 Bone Kabupaten Bone. Pascasarjana UIN Alauddin Makassar. Jurnal Diskursus Islam Volume 06 Nomor 3, December 2018 Hal 424 jam 8 bln 9 2019.diunduh senen tgl 2 sept 2019 jam 10 pagi.

Dost, E.N \& Hafshejani, N.K. (2017). The Impact of Teachers' Personality on Senior High School EFL Learners' General English Achievement. International Journal of English Literature and Social Sciences (IJELS) Vol-2, Issue-3, May - Jun, 2017. https://dx.doi.org/10.24001/ijels.2.3 .9 . Diunduh Pada Tanggal 18 Sepetember 2019 pukul 20.30 Wib

Fathurrahman, Pupuh, dan Sutikno, S. (2009). Strategi Belajar Mengajar. Bandung: Refika Aditama

Foster, D.J. (2012). Codes of Ethics in Australian Education: Towards a NationalPerspective. Australian Journal of Teacher Education Volume 37 Issue 9. Diunduh Pada Tanggal 18 Sepetember 2019 pukul 20.30 Wib

Garcia, P. (2011). Impact of Teacher Personality Styles on Academic Excellence of Secondary Students. National Forum of Teacher Education Journal. 21(3), 1-8. 
Ilanlou, M., \& Zand, M. (2011). "Professional Competencies of Teachers and the Qualitative Evaluation." Procedia-Social and Behavioral Sciences, 29, 11431150 . https://doi. org/10.1016/j.sbspro.2011.11.348

Iswidarmanjaya, D., dan Enterprise,. J. (2014). Satu Hari Lebih Percaya Diri. Gramedia. Jakarta.

Jamil, S. (2012). Guru Profesional. Yogyakarta: Ar. Ruzz Medi

Kunandar. (2014). Guru Profesional. Rajawali Pers: Jakarta.

Lickona,T. (2012), Mendidik Untuk Membentuk Karakter (Educating For Chaeacter). Jakarta: Bumi Aksara.

Mart, C.T. (2013). A Passionate Teacher: Teacher Commitment and Dedication to Student Learning. International Journal of Academic Research in Progressive Education and Development January 2013, Vol. 2, No. 1 ISSN: 2226-6348. Diunduh Pada Tanggal 18 Sepetember 2019 pukul 20.30 Wib.

Nahampun,. D. (2017). Kompetensi Kepribadian Guru Dalam Pelaksanaan Pembelajaran Anak Autis Di Slb C Karya Bhakti Purworejo. Jurusan Pendidikan Luar Biasa, Universitas Negeri Yogyakarya. Jurnal Widia Ortodidaktika Vol 6 No 5 Tahun 2017. Hal 538-546.di unduh tgl 8 September 2019, jam 21.00

Shabir,. U.,M. (2015). Kedudukan Guru Sebagai Pendidik: (Tugas dan Tanggung Jawab, Hak dan Kewajiban, dan Kompetensi Guru). Fakultas Tarbiyah dan Keguruan
UIN Alauddin Makassar Email: mshabiru@gmail.com.

AULADUNA, VOL. 2 NO. 2 DESEMBER 2015: 221-232 diunduh tanggal 8 september 2019 jam $22, .00$

Slameto. (2013). Belajar Dan FaktorFaktor Yang Mempengaruhi. Rhineka Cipta: Jakarta.

Sardiman. (2012). Interaksi Dan Moivasi Belajar Mengajar. Jakarta: Rajawali pers.

Undang-Undang Republik Indonesia Nomor 20 Tahun 2003 Tentang Sistem Pendidikan Nasional https://kelembagaan.ristikdikti.go.id >uploads $>2016 / 08$

Undang-Undang Republik Indonesia. Nomor 14 Tahun 2005. Tentang. Guru Dan Dosen. luk.staff.ugm.ac.id.>atur>UU142005 Guru dan Dosen

Sugiyono. 2(014). Metode Penelitian Kuantitatif, Kualitatif Dan $R \& D$. Alfabert: Bandung.

Suprihatiningrum,. J., (2014). Guru Profesional Pedoman Kinerja, Kualifikasi, \& Kompetensi Guru (Cet. II; Jogjakarta: Ar Ruzz Media) h. 106

Rochmawati, N.,(2018). Perang guru dan orang tua membentuk karakter jujur anak. Jurnal studi dan penelitian pendidikan Islam. Volume 1 Nomor 2 Agustus 2018. Di unduh tanggal 15 November 2019 jam 21.00. 